\title{
Irrigation Management in Potato (Solanum tuberosum L.) Production: A Review
}

\author{
Koffi Djaman ${ }^{1, * \mathbb{D}}$, Suat Irmak ${ }^{2}$, Komlan Koudahe ${ }^{3} \mathbb{D}$ and Samuel Allen ${ }^{1}$ \\ 1 Department of Plant and Environmental Sciences, Agricultural Science Center at Farmington, \\ New Mexico State University, P.O. Box 1018, Farmington, NM 87499, USA; samallen@nmsu.edu \\ 2 Biological Systems Engineering Department, University of Nebraska-Lincoln, 239 L.W. Chase Hall, \\ P.O. Box 830726, Lincoln, NE 68583, USA; sirmak2@unl.edu \\ 3 Biological and Agricultural Engineering Department, Kansas State University, 1016 Seaton Hall, \\ 920 N. 17th St., Manhattan, KS 66506, USA; koudahek@ksu.edu \\ * Correspondence: kdjaman@nmsu.edu
}

Citation: Djaman, K.; Irmak, S.; Koudahe, K.; Allen, S. Irrigation Management in Potato (Solanum tuberosum L.) Production: A Review. Sustainability 2021, 13, 1504. https:// doi.org/10.3390/su13031504

Academic Editor: José

Manuel Mirás-Avalos

Received: 6 January 2021

Accepted: 29 January 2021

Published: 1 February 2021

Publisher's Note: MDPI stays neutral with regard to jurisdictional claims in published maps and institutional affiliations.

Copyright: (c) 2021 by the authors. Licensee MDPI, Basel, Switzerland. This article is an open access article distributed under the terms and conditions of the Creative Commons Attribution (CC BY) license (https:// creativecommons.org/licenses/by/ $4.0 /)$.

\begin{abstract}
Limited water resources coupled with the increase of the human population calls for more efficient use of water in irrigated agriculture. Potato (Solanum tuberosum L.) is one of the most widely grown crops worldwide and is very sensitive to water stress due to its shallow rooting system. With the dilemma of potato sensitivity to drought and limited available water resources restricting crop production, researchers and crop growers have been investigating different approaches for optimizing potato yield and improving crop water use efficiency under different irrigation methods. While potato response to water is affected by other management practices such as fertilizer management, the present review is focused on the potato response to water under different environments and different irrigation methods and the impact on potato quality and potato diseases. Variable results obtained from research studies indicate the non-transferability of the results from one location to another as potato cultivars are not the same and potato breeders are still making effort to develop new high-yielding varieties to increase crop production and or develop new varieties for a specific trait to satisfy consumers exigence. This review is a valuable source of information for potato growers and scientists as it is not only focused on the impact of irrigation regimes on potato yield and water productivity as most reviews on water management, but it also presents the impact of irrigation regime on diseases in potatoes, tuber specific gravity, metabolite content of the tubers and the quality of the processed potato products.
\end{abstract}

Keywords: potato; irrigation; water productivity; disease; quality

\section{Introduction}

Global potato production is estimated at 370.4 million tons in about 17.34 million hectares and the production in the Americas was 45.1 million tons in about 1.54 million hectares; in Europe 107.26 million tons in 4.7 million hectares, in Oceania 1.74 million tons in 43,303 ha, in Asia 189.81 million tons in 9.30 million hectares, and in Africa 26.53 million tons in 1.76 million hectares in 2019 [1]. During the 2019 season, potato production across the United States was 21.22 million tons in about 937,300 hectares [2]. Potatoes are one of the most water-efficient crops and produce the greatest number of calories per unit of water input [3-5]. However, water management in potatoes is crucial as potato is one of the most water stress-sensitive crops due to its shallow rooting system [6-13] and the sensitivity of the potato foliage characteristics [14-17]. Sustainable water management is therefore required to optimize potato yield and water use efficiency while maintaining maximum tuber yield and quality. In this review, we explore study results in relation to water management options under rainfed, limited, and full irrigation under different irrigation methods in potato with possible impact on crop yield, water use efficiency, and the quality of the products. While other management practices might affect the outcome 
of different studies and the results, we are only focusing on water management and its impacts on potatoes in this review. This review covered the period of 1953-2021 with more focus on the 1990-2021 period dataset with results of studies across the main potato production areas such as the United States, Canada, Australia, New Zealand, and Turkey. Online search engines were used for published results collection from well-known scientific journals using target keywords.

\section{Potato Crop Water Use and Evapotranspiration}

Potato water use and evapotranspiration have been investigated by scientists across the globe and they vary with different factors including the irrigation methods, irrigation regimes, irrigation technology, local climates, fertilizer management options, and other management and environmental factors. Potato water demand for high tuber yield depends on climatic conditions and varied from 500 to $700 \mathrm{~mm}$ [18]. Haverkort [19] reported that potatoes water requirement ranged from 400 to $800 \mathrm{~mm}$ in Peru. Dimitrov [20] found potato water use that varied from 380 to $450 \mathrm{~mm}$ for optimum tuber yield. Potato evapotranspiration increased with irrigation applied rate of 33 to $100 \%$ of water requirement that varied from 316 to $630 \mathrm{~mm}$ at Davis, California [21]. Hane and Pumphrey [22] reported potato water use of $650 \mathrm{~mm}$, while for Sood and Sing [23], the potato water requirement was estimated at 350-650 mm. Ortega et al. [24] indicated that for production sustainability, it is necessary to consider seasonal irrigation amount equivalent to the range from 0.85 to 0.97 of maximum evapotranspiration while considering deficit irrigation for potato production in the province of Albacete in Spain. Karam et al. [25] found potato seasonal irrigation amount at 500-560 $\mathrm{mm}$ to reach the target yield under deficit irrigation. Under the Turkey climate conditions, Onder et al. [9] imposed four irrigation regimes as 0, 33, 66 , and $100 \%$ of full irrigation and found that potato seasonal irrigation amounts varied from 102 to $302 \mathrm{~mm}$ and from 88 to $268 \mathrm{~mm}$ in two consecutive growing seasons. Seasonal water use by potatoes in Saudi Arabia was $1505 \mathrm{~mm}$ [26]. Paredes et al. [27] reported potato seasonal irrigation amount of 330 and $237 \mathrm{~mm}$ in two consecutive years under full irrigation treatment while it was 165 and $118.5 \mathrm{~mm}$ under $50 \%$ of the full irrigation treatment under the Mediterranean condition in Southern Italy with seasonal precipitation of 278 and $181 \mathrm{~mm}$ in the respective years.

Potato water use varies with management practices and irrigation levels [28]. Potato seasonal evapotranspiration was $413.2 \pm 15 \mathrm{~mm}$ under drip irrigation in a loam soil while it was $362.1 \pm 16$ in clay soil in Valenzano, Italy [29]. Parent and Anctil [30] found a rainfed potato seasonal evapotranspiration to be $331.5 \mathrm{~mm}$ in 2007 in South-eastern Canada while they have reported the historical long-term average rainfed potato evapotranspiration of $563.3 \mathrm{~mm}$. They reported potato maximum daily evapotranspiration of $6.5 \mathrm{~mm} /$ day and it occurred during the potato tuber bulking. Yactayo et al. [31] found no impact on tuber yield when applying $50 \%$ of full irrigation through partial root-zone drying compared to full irrigation in Peru. Heritage potatoes (Moe Moe (S. tuberosum L.) and Tutaekuri (Solanum andigena Juz. and Buk.)) water requirements were 610 and $611 \mathrm{~mm}$ while the modern potatoes (Moon-light and Agria (S. tuberosum L.)) water requirements were 550 and $491 \mathrm{~mm}$ during the 2009-2010 and 2010-2011 seasons in New Zealand, respectively [32]. In a semiarid area in Gansu Province of China, rainfed potato seasonal evapotranspiration was a function of soil surface conditions and varied from 216.5 to $249.3 \mathrm{~mm}$, which seems relatively low compared to the findings of other studies [28]. Wellirrigated potato seasonal evapotranspiration was $445.2 \mathrm{~mm}$ in Erzurum-Turkey [33] and varied from 375.7 to $511.4 \mathrm{~mm}$ under arid climate in Iraq [34]. Under hot and dry climates in Spain, for the potato variety Desirée, evapotranspiration was a function of the applied irrigation amount and ranged from 150 to $550 \mathrm{~mm}$ [35]. Rainfed potato water use was only $195.2 \mathrm{~mm}$ in Turkey under the best water management [33].

Erdem et al. [36] reported the seasonal potato actual evapotranspiration (ETa) range as 445-683 mm in semiarid climatic conditions of Turkey. Seasonal actual evapotranspiration varied from 226 to $473 \mathrm{~mm}$ and from 166 to $392 \mathrm{~mm}$ when potatoes were subjected to 
full irrigation and 66, 33, and $0 \%$ of the full irrigation treatment. Fully irrigated potato seasonal evapotranspiration was $484 \mathrm{~mm}$ in 2009 and $355 \mathrm{~mm}$ in 2010 while it is $376 \mathrm{~mm}$ and $295 \mathrm{~mm}$ under $50 \%$ of full irrigation and the rainfed potato evapotranspiration was $219 \mathrm{~mm}$ and $186 \mathrm{~mm}$ under the Mediterranean condition in Italy [27]. Similarly, potato seasonal evapotranspiration varied with irrigation regimes, and the well-irrigated potato evapotranspiration was $448 \mathrm{~mm}$ in 2007 and $411 \mathrm{~mm}$ in 2008 in Sicily, Italy [37]. The findings of Ferreira and Carr [35], Shock et al. [38], Onder et al. [9], and Ati et al. [34] also relate to an increase in potato evapotranspiration with irrigation regime. Aksic et al. [39] reported that potato seasonal evapotranspiration varied with irrigation depths and ranged from 288.1 to $522.1 \mathrm{~mm}$ with the lowest value obtained under rainfed conditions while the highest value was obtained under the well-irrigated treatment. Potato seasonal water use under different irrigation methods and rainfed conditions across different locations is summarized in Table 1.

\section{Water Management in Potato}

\subsection{Irrigation Techniques vs. Potato Growth and Yield}

Different irrigation methods such as sprinkler, furrow, surface drip, and subsurface drip irrigation were used under potato production with different results according to the local climate and soil condition with contrasting outcomes in some studies. Onder et al. [9] compared surface drip and subsurface drip irrigation coupled with four irrigation regimes as $0,33,66$, and $100 \%$ of full irrigation and found that irrigation methods did not make significant differences in tuber yield. However, surface drip irrigation obtained the greatest water use efficiency and should be recommended under Mediterranean conditions for potato production $[9,40]$. Rolbiecki et al. [41] reported a 55\% increase in marketable yield of potato cultivar Courage compared to rainfed production in Poland. Slatni et al. [42] investigated the effect of alternate furrow irrigation, fixed furrow irrigation, and conventional furrow irrigation and found the average irrigation amounts were 65,60 , and $91 \mathrm{~mm}$, and the water productivity values amounted to $8.0,8.7$, and $5.9 \mathrm{~kg} \mathrm{~m}^{-3}$ for the respective treatments with no yield reduction under the alternate furrow irrigation. Xie et al. [43] compared conventional furrow irrigation with the partial root-zone drying irrigation system at different watering levels and found that applying $50 \%$ of the supplementary water requirement did not affect fresh tuber yield and water use efficiency under both irrigation methods. Under arid and semiarid conditions and low soil water retention capacity, the adoption of plastic mulching and drought-tolerant potato cultivars help to achieve high tuber yield and improve water and fertilizer use efficiency [43].

Sarker et al. [44] compared alternate furrow irrigation, fixed furrow irrigation, and every furrow irrigation and found that potato tuber yield, tuber quality, and potato water productivity were affected by alternate furrow irrigation in a raised bed system while potato yield did not differ significantly between the alternate furrow irrigation and every furrow irrigation system. Overall, alternate furrow irrigation saved $35 \%$ of irrigation water and significantly improved irrigation water productivity by $50 \%$ compared to every furrow irrigation treatment. The alternate furrow irrigation could be an alternative to every or fixed furrow irrigation in South Asian countries with limited irrigation water availability [44]. Trout et al. [45] found that Russet Burbank produces better visual quality tuber and much lower incidence of sugar ends under sprinkler irrigation than under furrow irrigation due to less water stress, better nitrogen management, and lower soil temperature under sprinkler irrigation compared to furrow irrigation. 
Table 1. Potato seasonal water use under different irrigation methods and rainfed conditions across different locations.

\begin{tabular}{|c|c|c|c|c|c|c|c|c|}
\hline Locations & $\begin{array}{c}\text { Seasonal } \\
\text { Precipitation }(\mathrm{mm})\end{array}$ & $\begin{array}{c}\text { Watering } \\
\text { Regime }\end{array}$ & $\begin{array}{l}\text { Irrigation Amount } \\
(\mathrm{mm})\end{array}$ & $\begin{array}{c}\text { Seasonal Water Use } \\
(\mathrm{mm})\end{array}$ & Irrigation Method & Seasonal ETc $(\mathrm{mm})$ & Potato Cultivar & Reference \\
\hline $\begin{array}{l}\text { Oregon } \\
\text { India }\end{array}$ & & & & $\begin{array}{c}649 \\
350-650\end{array}$ & Sprinkler irrigation & $300-655.1$ & Russet Burbank & $\begin{array}{l}\text { Hane and Pumphrey [22] } \\
\text { Sood and Sing [23] }\end{array}$ \\
\hline Lebanon & & & $562.9-638.3$ & & Drip irrigation & $490-622$ & Agria & Karam et al. [25] \\
\hline Turkey & $142-512$ & Irrigated & 88 to 302 & $244-780$ & Drip irrigation & $166-473$ & Marfona & Onder et al. [9] \\
\hline Saudi Arabia & & Irrigated & $783-1505$ & $783-1505$ & Drip irrigation & & & El-Abedin et al. [26] \\
\hline Italy & $181-278$ & Irrigated & $118.5-330$ & $299-608$ & Drip irrigation & $295-484$ & Spunta & Paredes et al. [27] \\
\hline Italy & $171-282$ & Rainfed & & & & 186-219 & Spunta & Paredes et al. [27] \\
\hline Italy & & Irrigated & & $413.2 \pm 15$ & Drip irrigation & $322.2-447.9$ & Spunta & Katerji et al. [29] \\
\hline Canada & 350.6 & Rainfed & & & & 331.5 & Reba & Parent and Anctil [30] \\
\hline Peru & Desert with $23 \mathrm{~mm}$ & Irrigated & $102.3-222.5$ & & Furrow & & UNICA & Yactayo et al. [31] \\
\hline New Zealand & $294.6-421.6$ & Irrigated & $189.4-196.4$ & $491-550$ & Sprinkler irrigation & $491-611$ & Agria, Moonlight, & Fandika et al. [32] \\
\hline New Zealand & & Rainfed & & $491-550$ & & & Moe Moe, Tutaekuri & Fandika et al. [32] \\
\hline China & $150.9-208.2$ & Rainfed & & $150.9-208.2$ & & 216.5 to 249.3 & Kexin 1 & Chen et al. [28] \\
\hline Turkey & $59.3-156.7$ & Rainfed & & 195.2 & & $167.7-222.6$ & & Kiziloglu et al. [33] \\
\hline Turkey & $59.3-156.8$ & Irrigated & & 445.2 & Surface irrigation & up to 475.2 & Granola & Kiziloglu et al. [33] \\
\hline Iraq & 7.4 & & $300-447$ & $307.4-455.4$ & Furrow \& drip irrigation & $375.1-511.4$ & Bowren & Ati et al. [34] \\
\hline Portugal & & & & - & - & 150 to 550 & Desirée & Ferreira and Carr [35] \\
\hline Turkey & $50-111$ & Irrigated & 293-675 & $404-626$ & Furrow \& drip irrigation & $464-683$ & & Erdem et al. [36] \\
\hline Italy & 170-196 & Irrigated & 25-191 & 195-382 & Drip irrigation & $155-448$ & Spunta & Ierna and Mauromicale [37] \\
\hline Ontario, Oregon & & Irrigated & $368-588$ & $368-589$ & Sprinkler irrigation & - & Russet & Shock et al. [38], \\
\hline
\end{tabular}




\subsection{Impact of Irrigation Regime on Potato Growth and Yield}

Potato plants have a shallow rooting system which makes them very sensitive to water stress, requiring proper water management to avoid putting potato plants under drought conditions $[6,8,9,11,12]$. For potato production sustainability, moisture should be kept above $50 \%$ of the total available water of the site soil [46]. Jensen et al. [47] reported that $30 \%$ was the water-saving limit compared to the field capacity. Camargo et al. [48] suggested that applying 80 to $100 \%$ of irrigation requirements helps to achieve high biomass accumulation. Potato growth, yield, and yield component are affected by irrigation regimes mostly tuber bulking and ripening which are the water stress-sensitive stages [49]. Foti et al. [50] reported no significant yield difference between 100 and $66 \%$ of maximum evapotranspiration irrigation regimes on potato tuber yield while they obtained the highest tuber yield with $133 \%$ maximum evapotranspiration water supply. In contrast, Karafyllidis et al. [51] obtained the highest potato yield under $65 \%$ of maximum evapotranspiration. Iqbal et al. [52] reported that the potato growing stage is the least sensitive to water stress. Deficit irrigation strategies aim to expose crops to a certain level of water stress during either a particular growth stage or during the crop growing season with a non-significant impact on crop yield [53]. Fresh potato yield and total dry matter accumulation increase with water supply [48,54-57]. Potato tuber number per plant and total yield increase with adequate irrigation water management before and during tuber initiation [58-60] and the proper irrigation management after tuber initiation increases the size of tubers [61-65]. During a two-year experiment in the Central Bekaa Valley of Lebanon, Karam et al. [25] found the full irrigation treatment to overcome deficit irrigation at tuber bulking and tuber ripening by 12 and $43 \%$, in the first year and 11 and 39\% in the second year, respectively. Similarly, Fabeiro et al. [66] reported potato yield reduction under deficit irrigation during potato growth, tuber bulking, and ripening stages while the larger tubers were obtained under the fully irrigated potato and the ripening stage deficit irrigation, and the smallest tubers were obtained under the applied deficit irrigation during the growth period with a high tuber number per plant. Deblonde and Ledent [14] reported a 17\% reduction in potato tuber number of six cultivars affected by water stress at Nodebais, Belgium, with no impact on the yield due to compensation by average tuber dry weight. Brocic et al. [67] reported yield reduction of potato cultivar Liseta under $70 \%$ partial root-zone irrigation and silty-clay soil compared to the full irrigation. Karam et al. [25] found a $12 \%$ and $42 \%$ reduction in potato marketable yield when deficit irrigation was imposed at tuber bulking and tuber ripening, respectively, compared to the well-irrigated treatment. Yield loss under deficit is compensated by an increase in tuber dry matter [25,55]. Yuan et al. [68] reported that potato fresh tuber and marketable yield increased with increasing irrigation regimes. Miller and Martin [69] reported that daily irrigation improved total tuber yield, the number of tubers, and the specific gravity compared to four-day interval irrigation. Byrd et al. [70] showed the potential for reduced irrigation management for sustainable potato production in Florida. Camargo et al. [48] found $80 \%$ of irrigation requirements showed statistically similar yields to 100 and $120 \%$ of irrigation requirements in Aguas Nuevas, Spain.

Comparing deficit irrigation and partial root-zone drying with full irrigation, ElAbedin et al. [26] found that the deficit treatment and partial root-zone drying decreased potato fresh and dry tuber yield compared to the full irrigation with no difference between the treatments for the number of marketable size tubers while the number of oversized tubers was significantly lower under the partial root-zone treatments than under the full irrigation treatment. They indicated that the highest number of tubers per plant was obtained under full irrigation treatment and the deficit irrigation at $50 \%$ of the full irrigation treatment produced $51 \%, 72.8 \%$, and $136.9 \%$ more tubers than the deficit irrigation at $70 \%$, partial root-zone drying at $70 \%$ and partial root-zone drying at $50 \%$, respectively. Karam et al. [25] reported that $50 \%$ of tuber yield was constituted with the large size potatoes $(>200 \mathrm{~g})$ under the full irrigation treatment while that proportion was $48 \%$ under the deficit irrigation at tuber bulking and $46 \%$ under deficit irrigation at tuber ripening. A larger number of small tubers was obtained when deficit irrigation was applied during the 
tuber bulking stage compared to the tuber ripening state. Wang et al. [71] reported that potato tuber yield, largest tuber weight, commodity tuber weight, dry matter accumulation, and vitamin $C$ content increased with the increase in the fertilizer application rate and the dripper discharge rate. Elhani et al. [72] also demonstrated that tuber yield penalty was similar under partial root-zone drying compared to deficit irrigation. These management approaches may be used by potato seed producers for increasing the number of potato seeds per plant.

\subsection{Potato Water Production Function}

Linear relationships were developed between potato yield and the seasonal evapotranspiration with different regression slopes and different intercepts under different environments $[37,66,68]$. These regression relationships were impacted by the management practices, potato cultivars, and fertilization. Cappaert et al. [60] indicated that the greatest effect of the irrigation management during the potato tuber ripening stage is shown by the magnitude of the coefficient of the applied irrigation amount during ripening (w3) within the linear production function. Kiziloglu et al. [33] found a linear relationship between potato yield and crop evapotranspiration with an $\mathrm{R}^{2}$ of 0.94 in Turkey. A similar relationship was reported by Islam et al. [73], Unlu et al. [74], Ayas and Korukçu [75], Cantore et al. [76], and Camargo et al., [48]. Unlu et al. [74] reported a difference in the regression slopes between the sprinkler and trickle irrigation systems with high water productivity under sprinkler irrigation than under trickle irrigation in Turkey. In contrast, Aksic et al. [39] reported a quadratic relation between potato yield and crop evapotranspiration in Serbia.

Linear production function was developed by Fabeiro et al. [66] where potato cultivar Agria tuber yield is a function of the amount of irrigation applied (wi) during potato growth (w1), tuber bulking (w2), and ripening (w3) stages in Spain [yield $=44.65 \mathrm{w} 1+17.14 \mathrm{w} 2$ $\left.+242.41 \mathrm{w} 3 ; \mathrm{R}^{2}=0.993\right]$. The same authors also reported quadratic relationship between tuber yield and the seasonal applied water $(w)$ [yield $=38.067-0.0087 w+0.000001639 w^{2}$; $\mathrm{R}^{2}=0.742$ ]. Ross [77] found a cubic polynomial relationship between potato yield and the seasonal applied irrigation water amount. Badr et al. [78] found a linear relationship between potato tuber yield and the seasonal water supply with a quite high $\mathrm{R}^{2}$ value of 0.973 and a regression slope of $92 \mathrm{~kg} / \mathrm{ha}$ for unit mm of applied water. Yuan et al. [68] reported a quadratic relationship between potato yield per plant and the irrigation water supply (w) with $\mathrm{R}^{2}$ of 0.98 [yield $=-0.0092 \mathrm{w}^{2}+7.52 \mathrm{w}-409.47$ ]. Karam et al. [25] found a strong quadratic relationship between fresh potato tuber yield (Cultivar Agria) (kg/ha) and the seasonal applied irrigation amount $\mathrm{w}(\mathrm{mm})$ with $\mathrm{R}^{2}$ value of 0.82 [yield $=-0.9277 \mathrm{w}^{2}+$ $\left.1184.3 \mathrm{w}-314,999.9 ; \mathrm{R}^{2}=0.82\right]$.

Overall, potato yield has a strong linear relationship with crop seasonal evapotranspiration while it has a polynomial relationship with the seasonal applied irrigation amounts. However, these relationships may greatly vary in terms of the linear regression slopes, the intercepts, the constants within the polynomial, and the coefficient of determination as influenced by crop management practices, irrigation methods and scheduling, potato genotypes, soil types, climatic conditions, and other factors.

\subsection{Potato Water Use Efficiency (WUE)}

Potato has been reported to have a high water use efficiency (WUE) among the major food crops and which varied from 6 to $11.6 \mathrm{~kg} / \mathrm{ha} / \mathrm{m}^{3}$ [4]. However, potato WUE strongly depends on the genetic material, management practices, irrigation regime, fertilizer rate, and other environmental conditions. Modern potatoes have high WUE, but they are not as economically productive under the same volume of water as heritage potatoes [32]. Deficit irrigation strategies in crops are revealed to optimize crop WUE [79-84]. Onder et al. [9] reported potato irrigation water use efficiency (IWUE) that varied from 9.33 to $36.44 \mathrm{~kg} / \mathrm{ha} / \mathrm{m}^{3}$ under surface drip irrigation and from 9.05 to $30.12 \mathrm{~kg} / \mathrm{ha} / \mathrm{m}^{3}$ with the greatest IWUE obtained by treatment $33 \%$ of maximum evapotranspiration. The total water productivity varied from 6.17 to $14.01 \mathrm{~kg} / \mathrm{ha} / \mathrm{m}^{3}$ [9]. Yactayo et al. [31] reported an increase 
in potato water use efficiency with an early partial root-zone drying, initiated 6 weeks after planting, with a watering level equivalent to $50 \%$ of full irrigation, with no yield reduction compared to fully irrigated potato in Peru. Potato economic water use efficiency, which is the reflection of marketable yield, varies with cultivars, irrigation regimes fertilization [32]. Ahmadi et al. [85,86] reported a significant decrease in potato IWUE under the partial root-zone drying (31-41\%) compared to the full irrigation treatment. Fandika et al. [32] found potatoes WUE varying from 5.2 to $11.8 \mathrm{~kg} / \mathrm{ha} / \mathrm{m}^{3}$ under irrigation, from 9.0 to $12.9 \mathrm{~kg} / \mathrm{ha} / \mathrm{m}^{3}$ under rainfed production and was $8.3 \mathrm{~kg} / \mathrm{ha} / \mathrm{m}^{3}$ under $80 \mathrm{~kg} \mathrm{~N} / \mathrm{ha}$ and $7.0 \mathrm{~kg} / \mathrm{ha} / \mathrm{m}^{3}$ under $240 \mathrm{~kg} \mathrm{~N} /$ ha in New Zealand. WUE decreased therefore with increasing irrigation regimes and increasing nitrogen applied rates. Paredes et al. [27] also found an increase in the IWUE under 50\% deficit irrigation compared to the full irrigation treatment. They pointed to large IWUE differences between irrigation treatments as also shown by Trebejo and Midmore [87] and Ahmadi et al. [88] however, the differences were small between treatments when the seasonal precipitation, total water supply, and seasonal crop evapotranspiration were considered [27,42,89]. Chen et al. [28] indicated that straw strips mulch on furrows improved rainfed potato WUE by up to $74.8 \%$ and yield from 36.6 to $61.2 \%$ in Dingxi City, Gansu Province, China. El-Abedin et al. [26] found a reduction in potato irrigation water use efficiency (IWUE) by 33.8 and $36.1 \%$ under partial root-zone drying 70 and $70 \%$ compared to the full irrigation in 2014, respectively, while the reduction was 26.6 and $46.6 \%$ under the respective treatments in 2015 . They also found that deficit irrigation at 70 and $50 \%$ of the full irrigation also decreased potato IWUE by 18.94 and $22.19 \%$, respectively one year over two. However, the deficit irrigation a 70 and $50 \%$ of the full irrigation treatment showed higher IWUE (5.80 and $6.30 \mathrm{~kg} / \mathrm{ha} / \mathrm{m}^{3}$ ) than the partial root-zone drying technology at the same rates $\left(4.41\right.$ and $\left.3.21 \mathrm{~kg} / \mathrm{ha} / \mathrm{m}^{3}\right)$. The improvement in IWUE under deficit irrigation compared to the partial root-zone drying was reported by Liu et al. [90]. Kriedmann and Goodwin [91] indicated that yield maintenance and IWUE improvement are the advantages of the partial root-zone drying technology over the regular deficit irrigation strategy. Partial root-zone drying has improved potato IWUE in the United Kingdom [92]. Under arid and semiarid climates, the duration of the wet/dry cycling in the partial root-zone drying decreases, and the crop is not exposed to extreme and severe water stress compared to the classic deficit irrigation [26,93]. Moreover, the partial root-zone drying practice should be started five to six weeks after tuber initiation [31,82,94]. In contrast, Shahnazari et al. [95], Ahmadi et al. [85] and Jovanovic et al. [96] reported higher potato IWUE under the partial root-zone drying than under deficit irrigation. Potato yield was similar under partial root-zone drying, deficit irrigation, and full irrigated potato while the partial root-zone drying and the deficit irrigation improved IWUE by $60 \%$ with $30 \%$ of the irrigation water saving in Denmark. Similarly, Liu et al. [97] found no potato yield improvement and IWUE under partial root-zone drying compared to the classic deficit irrigation. El-Abedin et al. [26] indicated that the contrasting results might have resulted from differences in the experiment set up, potato cultivars, climate, soil types, root distribution, and soil water balance.

\subsection{Impact of Irrigation on Diseases in Potatoes}

Potatoes are grown under different irrigation methods as surface irrigation, drip irrigation, and sprinkler irrigation. Irrigation management is critical for the management of fungal and bacterial diseases in potato crops such as hallow heart, late blight, early blight, while mold, bacteria stem rot, early drying, bacterial ring rot, etc. High and continuous humidity within potato crop canopy is favorable for pathogen germination and growth, reproduction, dispersal, and survival [98]. Irrigation can 'create a favorable environment for potato soil-borne diseases such as Rhizoctonia canker and black scurf (Rhizoctonia solani), common scab (Streptomyces scabiei), powdery scab (Spongospora subterranea f. sp. Subterranean), white mold (Sclerotinia sclerotiorum), silver scurf (Helminthosporium solani) pink rot (Phytophthora erythroseptica) and Verticillium wilt (Verticillium dahlia). Sprinkler irrigation, an overhead irrigation method creates high humidity on the potato leaves and within the 
canopy, creating a micro-climate favorable to the development of potato foliage diseases such as early blight, late blight, bacterial stem rot, and white mold. It is therefore important to allow foliage to dry between irrigation and late afternoon and early evening irrigation events keep leaves wet during the night, which may increase the potential of occurrence of late blight, should be avoided [99]. While drip irrigation is usually assessed as water-saving technology, it has limited potential to create favorable conditions for potato foliar diseases. In contrast, recurrent mite infestations may increase mostly under subsurface drip-irrigated potato production. Menzies [100] reported that sprinkler irrigation increases the occurrence of fungal and bacterial folial diseases. During the planting-sprouting stage, irrigation may increase soil moisture content while the potato seeds have enough moisture to support sprouting to emergence. Any irrigation event during that stage will decrease soil aeration to a level that is favorable to several pathogens, most notable bacterial soft rot or black leg (Erwinia carotovora), and stem and stolon canker (Rhizoctonia solani) development [101]. Rupp and Jacobsen [102] suggested avoiding over-irrigation to control aerial stem rot and early blight and recommended the use of less frequent irrigation with longer duration and early day irrigation to allow for drying to occur later in the day, and no irrigation should occur in cool cloudy conditions. Alternaria brown spot known as brown leaf spot caused by the fungus Alternaria alternata, is more severe with overhead irrigation. The soft bacterium is spread by irrigation, splashing water, or insects. In contrast, the potato common scab (Streptomyces scabies) on the potato cultivar Russet Burbank was controlled by maintaining soil moisture content above $90 \%$ of the total soil available water during six to nine weeks. Olanya et al. [103] have compared the microclimate created by sprinkler irrigation, surface drip irrigation, and subsurface drip irrigation on Russet Burbank potato in Maine (USA) and found that the irrigation application method did not consistently impact microclimatic parameters associated with late blight development. Larkin et al. [104] found an increase in potato back surf caused by Rhizoctonia solani and common scab caused by Streptomyces scabiei under irrigated treatment compared to rainfed treatment. However, previous research showed that irrigation during the six weeks following tuber initiation tends to reduce common scab in potatoes [105,106]. Davis and Everson [107] reported more severe Verticillium wilt in potato under furrow irrigation than under sprinkler irrigation. Irrigation can also be used in combination with pesticides as chemigation to control foliage pests in potatoes if the product is allowed chemigation.

Diverse diseases in potatoes are transmitted by mostly phytophagous pests feeding on the vascular system of the potato plant. For example, the potato psyllid (Bactericera cockerelli) is one of the most important pests in potatoes (Solanum tuberosum L.) due to its feeding behavior and the transmission of a bacterium (Candidatus Liberibacter solanacearum) that causes zebra chip disease, altering the quality of the potato tuber and the fried potato chips or French fries [108-112]. Aphids especially the green peach aphid (Myzus persicae) and Potato aphid (Macrosiphum euphorbiae) transmit potato leafroll virus which reduces marketable potato yield causing phloem net necrosis, a brown discoloration inside the potato that reduces quality and other viruses cucumber mosaic and alfalfa mosaic (calico) inducing a wide variety of foliar and tuber symptoms, leading to severe yield reduction and loss of tuber quality [113,114]. Myzus persicae, Rhopalosiphum padi, Aphis fabae, and others are well known to transmit Potato Virus Y (PVY) which impacts potato yield and quality $[115,116]$. When aphids' infestation occurs, irrigation should be stopped to allow slow dehydration of potato foliage and desiccation which triggers wind formation in aphids and stimulus for flights [117]. However, this should be the last option as reducing and stopping irrigation may be detrimental to potato tuber yield and quality.

Spider mites are basically abundant under severe drought and hot conditions and they colonize stressed plants under poorly managed irrigation scheduling [118]. Mites Tetranychus urticae and Polyphagotarsonemus latus (Arachnidae: Trombidiformis, Tarsonemidae) are polyphagous and can build high populations in a very short time during the hot dry season when the air temperature is above $30^{\circ} \mathrm{C}$. The fungal potato pathogen Streptomyces spp is associated with mite and causes scab in potatoes [119]. Besides the chemical control, 
sprinkler irrigation helps to limit mite damage by increasing the humidity on plant leaves $(>60 \%)$.

The potato tuberworm, Phthorimaea operculella (Zeller) (Lepidoptera: Gelechiidae) is a major pest in potatoes that feed on potato leaves with less significant yield lost and tuber infestation reduces the marketable yield. The larvae mine leaves, stems, petioles, and excavate tunnels through potato tubers, which is considered the typical damage. Insecticide application is the main method used to control the pest however, cultural practices such as irrigation management are used for sustainable management. Meisner et al. [120] reported that the female moths prefer dry soil for oviposition and the larvae survival increases with low soil moisture content [121]. It is therefore important to keep soil moisture high through sprinkler irrigation and avoid cracks in the soil mostly during the late-season stage with vine senescence, and after vine kill. Rondon et al. [122] and Clough et al. [123] suggested that applying $2.5 \mathrm{~mm}$ /day through a center pivot irrigation system from vine kill to harvest decreased $P$. operculella tuber damage and did not increase fungal or bacterial diseases. Table 2 summarizes some irrigation management favoring diseases in potatoes and other water management to reduce the impact of the diseases.

Table 2. Irrigation management favoring diseases in potatoes and irrigation practices to reduce the impact of the diseases.

\begin{tabular}{|c|c|c|c|c|}
\hline Disease & Pathogen & Favorable Conditions & $\begin{array}{l}\text { Irrigation Practices to } \\
\text { Reduce the Diseases }\end{array}$ & Reference \\
\hline $\begin{array}{l}\text { fungal and bacterial } \\
\text { folial diseases. }\end{array}$ & Fungi and bacteria & $\begin{array}{l}\text { High-frequency sprinkler } \\
\text { irrigation }\end{array}$ & $\begin{array}{l}\text { Less frequent high rate } \\
\text { irrigation and early day } \\
\text { irrigation }\end{array}$ & [100] \\
\hline $\begin{array}{l}\text { bacterial soft rot or } \\
\text { black leg }\end{array}$ & Erwinia carotovora & \multirow{2}{*}{$\begin{array}{l}\text { Irrigation during Planting } \\
\text {-sprouting stage }\end{array}$} & \multirow{2}{*}{$\begin{array}{l}\text { No irrigation during } \\
\text { Planting-sprouting stage }\end{array}$} & [101] \\
\hline stem and stolon canker & Rhizoctonia solani & & & [101] \\
\hline aerial stem rot & $\begin{array}{l}\text { Phytophthora nicotianae, } \\
\text { Pectobacterium } \\
\text { carotovorum, } \\
\text { Pectobacterium } \\
\text { atrosepticum, Dickeya } \\
\text { dianthicola }\end{array}$ & $\begin{array}{l}\text { Sprinkler over-irrigation, } \\
\text { dense canopies, excessive } \\
\text { nitrogen fertilization }\end{array}$ & $\begin{array}{l}\text { Avoid over-irrigation, use } \\
\text { less frequent irrigation, } \\
\text { with longer durations. } \\
\text { Early day irrigation }\end{array}$ & [102] \\
\hline Potato comment scab & Streptomyces scabies & over-irrigation & $\begin{array}{c}\text { Soil moisture content }> \\
90 \% \text { total soil available } \\
\text { water during } 6 \text { to } 9 \text { weeks }\end{array}$ & [102] \\
\hline Ring rot & Clavibacter michiganensis & Drought and heat stress & Keep surfaces wet & [102] \\
\hline Alternaria brown spot & Alternaria alternata & Overhead irrigation & $\begin{array}{l}\text { Avoid irrigation in cool, } \\
\text { cloudy conditions }\end{array}$ & [102] \\
\hline Early blight & Alternaria solani & Overirrigation & $\begin{array}{l}\text { Avoid over-irrigation, } \\
\text { allow leave to fully dry }\end{array}$ & [102] \\
\hline Late blight & Phytopthora infestans & Overhead irrigation during & $\begin{array}{l}\text { Monitor irrigation so that } \\
\text { leaves dry during the day, } \\
\text { avoid excessive } \\
\text { fertilization }\end{array}$ & {$[102,103]$} \\
\hline Potato back & Rhizoctonia solani & Irrigated cropping & $\begin{array}{l}\text { regulated deficit irrigation } \\
\text { Safe deficit irrigation }\end{array}$ & [104] \\
\hline Common scab & Streptomyces scabiei & Irrigated cropping & $\begin{array}{c}\text { irrigation during the } \\
6 \text { weeks following tuber } \\
\text { initiation }\end{array}$ & [104-106] \\
\hline Verticillium wilt & Verticillium dahliae & Furrow irrigation & $\begin{array}{l}\text { Sprinkler irrigation, } \\
\text { irrigation management } \\
\text { prior to tuber initiation) }\end{array}$ & [107] \\
\hline Zebra chip & $\begin{array}{l}\text { Candidatus Liberibacter } \\
\text { solanacearum }\end{array}$ & Bactericera cockerelli & $\begin{array}{l}\text { Stop irrigation for leaf } \\
\text { dehydration and } \\
\text { desiccation }\end{array}$ & [108-112] \\
\hline
\end{tabular}


Table 2. Cont.

\begin{tabular}{cccc}
\hline Disease & Pathogen & Favorable Conditions & $\begin{array}{c}\text { Irrigation Practices to } \\
\text { Reduce the Diseases }\end{array}$ \\
\hline PVY & Potato virus $Y$ & $\begin{array}{c}\text { Myzus persicae, } \\
\text { Rhopalosiphum padi, } \\
\text { Aphis fabae }\end{array}$ & $\begin{array}{c}\text { Stop irrigation to allow } \\
\text { slow dehydration of potato } \\
\text { foliage and desiccation }\end{array}$ \\
$\begin{array}{c}\text { Tetranychus urticae, } \\
\text { Polyphagotarsonemus } \\
\text { latus }\end{array}$ & $\begin{array}{c}\text { Drought and heat stress } \\
\left.\text { (temperature }>30^{\circ} \mathrm{C}\right)\end{array}$ & $\begin{array}{c}\text { Sprinkler irrigation helps } \\
\text { to limit mite damage }\end{array}$ \\
$\begin{array}{c}\text { scab in potatoes } \\
\text { associated with mites }\end{array}$ & Streptomyces spp & $\begin{array}{c}\text { Drought and heat stress } \\
\left.\text { (temperature }>30^{\circ} \mathrm{C}\right)\end{array}$ & $\begin{array}{c}\text { Sprinkler irrigation helps } \\
\text { to limit mite damage }\end{array}$ \\
\hline
\end{tabular}

\subsection{Impact of Irrigation Regime on Potato Specific Gravity and Chemical Content of the Tubers}

Specific gravity is one of the characteristics of potato tuber, and determinant for harvest quality. It is a measurement of the starch or solids content relative to the water content in a potato. High dry matter content is a synonym of low water content and vice versa. It is used by the potato industry for harvest storability, fry quality appreciation, and baking characteristics. Miller and Martin [69] reported that daily irrigation increased potato specific gravity compared to four-day interval irrigation. Yuan et al. [68] indicated that specific gravity tended to decrease with increasing irrigation depth. In contrast, water stress in potato improves the chip quality due to the higher content of tuber dry matter [124]. However, Hang and Miller [125] and Shock et al. [65] indicated that deficit irrigation trended to decrease tuber specific gravity. Similar findings were reported by Waddell et al. [126] who found that the specific gravity of tubers from the relatively stressed treatments was significantly lower than the specific gravity of tubers from the well-irrigated treatment under sprinkler irrigation. Poter et al. [127] found that tuber-specific gravity decreased with increasing irrigation rates while Drewitt [128] reported an increase in specific gravity with an increase in irrigation frequency. Early appropriate stages irrigation increases tuber dry matter and continuous or late-season irrigation can reduce potato dry matter content [129]. Peterson and Weigle [130] indicated that tuber specific gravity increased under mist irrigation conditions. Reduction in tuber-specific gravity associated with late-season irrigation was reported by Silva et al. [131]. After wine kill, tuber specific gravity decreases with desiccation [132,133].

Studies have revealed that irrigation management can affect the quality of the production and the chemical composition of tubers during the storage period which is particularly critical for the chip potato industry. Potato dry weight is constituted mainly by starch and small quantities of sugars, fiber, protein, and ash. Potato tuber content in sucrose, glucose, and fructose are important factors affecting the color of the processed products such as French fries and chips in potatoes [134,135]. Jovanovic et al. [96] pointed that the partial root-zone drying irrigation management results in a slight reduction in soluble sugar content and an increase in starch, nitrogen, and antioxidant contents of potato tubers. Sarker et al. [44] found potato soluble sugar also varied significantly between the alternate furrow irrigation and every furrow. Eldredge et al. [64] found an increase in potato tuber sugar content promoted by drought stress. Comparing partial root-zone drying to deficit irrigation, Elhani et al. [72] reported a decrease in potato tuber sugar and protein content with the increase in water stress with higher values in partial root-zone drying than in deficit irrigation treatment as shown by Battilani et al. [136]. Adversely, the polyphenols and antioxidants amount increased in potato tubers with increasing water stress on potato plants. There was also higher metabolite content in potato tubers under partial root-zone drying than under deficit irrigation with less decrease in glucose and fructose concentrations and with double the amount of mannitol [72]. In contrast, Elhani et al. [72] found that tuber content in glucose and fructose gradually decreased with decreasing seasonal water supply and similar findings were reported by Wegener et al. [137] who reported a decrease in total sugars, glucose, and fructose with increasing water stress in potatoes. 
The inconsistency of the effect of the drought stress on the sugar content of the tubers is genotype/cultivar dependent $[138,139]$.

Protein content in the potato tubers is an important nutritional characteristic [140] and is usually impacted by the irrigation regime and plant nitrogen fertilizer uptake and remobilization. Plant nitrogen content decreases under drought conditions [141]. However, Elhani et al. [72] reported an increase in potato tuber protein content under the partial root-zone drying treatment, and which might have been possible due to the increase in nitrogen mineralization with the increase of the frequency of the wet/dry cycles $[47,142]$ or the promotion of nitrogen uptake [143].

Polyphenols are the other main constituents of potatoes which are influenced by crop water management. Hamouz et al. [144] found that the polyphenols contents were increased under drought stress compared to the well-irrigated treatment under extreme temperature. Elhani et al. [72] reported an increase in tuber polyphenols content with an increase in water stress. This phenomenon is due to the alteration of sucrose flux induced by water stress which changes the expression of the responsible polyphenol synthesis genes [138]. Andre et al. [138] indicated that there is a correlation between diverse polyphenolic profiles and the variations in gene expression profiles and the droughtinduced variations of the gene expression were highly genotype-specific. Some potato tuber quality indexes as impacted by management practices are summarized in Table 3 with the best water management practice to reduce the induced unfavorable quality.

Table 3. Potato tuber quality as impacted by management practices.

\begin{tabular}{|c|c|c|c|c|}
\hline Quality Index & Trend & Cause & Best Practices & Reference \\
\hline Specific gravity & Decrease & Four-day irrigation scheduling & Daily irrigation & Miller and Martin [69] \\
\hline Specific gravity & Decrease & High irrigation rate & Meet crop ETc & Yuan et al. [68] \\
\hline Specific gravity & & & Meet crop ETc & {$[124]$} \\
\hline Specific gravity & Decrease & Deficit irrigation & Meet crop ETc & Hang and Miller [125] \\
\hline Specific gravity & Decrease & Deficit irrigation & Meet crop ETc & Shock et al. [65] \\
\hline Specific gravity & Decrease & Drought & Meet crop ETc & Waddell et al. [126] \\
\hline Specific gravity & Decrease & Increasing irrigation & Meet crop ET & Poter et al. [127] \\
\hline Specific gravity & Increase & High irrig. frequency & & Drewitt [128] \\
\hline Specific gravity & Decrease & Continuous late irrigation & $\begin{array}{l}\text { Reduce irrigation frequency } \\
\text { late season }\end{array}$ & {$[129,131]$} \\
\hline Specific gravity & Increase & Mist irrigation & & Peterson and Weigle [130] \\
\hline Specific gravity & Decrease & Desiccation after wine kill & Light irrigation after Wine kill & {$[132,133]$} \\
\hline Sugar content & Reduce & PRZDI & Meet crop ETc & Jovanovic et al. [96] \\
\hline Sugar content & Reduce & Alternate Furrow & Every furrow & Sarker et al. [44] \\
\hline Sugar content & Increase & Drought & & Eldredge et al. [64] \\
\hline Sugar content & Decrease & Drought & Meet crop ETc & Elhani et al. [72] \\
\hline Sugar content & Decrease & Deficit irrigation & PRZDI & Battilani et al. [136] \\
\hline $\begin{array}{l}\text { Metabolite Mannitol } \\
\text { content }\end{array}$ & Increase & Deficit irrigation & Meet crop ETc & Elhani et al. [72] \\
\hline Sugar contents & Decrease & Water stress & Meet crop ETc & {$[72,137]$} \\
\hline Sugar Ccontent & Inconsistent & \multicolumn{2}{|c|}{ genotype/cultivar dependent } & {$[138,139]$} \\
\hline Protein content & Decrease & Drought & Meet crop ETc & [141]. \\
\hline Protein content & Increase & PRZDI & & {$[47,72,142,143]$} \\
\hline Polyphenols & Increase & Drought & Meet crop ETc & {$[72,144,145]$} \\
\hline $\begin{array}{c}\text { Sugar end / called dark } \\
\text { ends }\end{array}$ & Increase & Heat, drought & Meet crop ETc & {$[59,146-154]$} \\
\hline Sucrose & Increase & Water stress & Meet crop ETc & Thompson et al. [150] \\
\hline phenyl-propanoids & Increase & Drought & Meet crop ETc & {$[155-158]$} \\
\hline $\begin{array}{c}\text { Sugar end / called dark } \\
\text { ends }\end{array}$ & Increase & Excessive nitrogen fertilizer & Meet crop need & {$[155,156]$} \\
\hline $\begin{array}{c}\text { Sugar end/called dark } \\
\text { ends }\end{array}$ & Increase & $\begin{array}{l}\text { Inadequate phosphorus } \\
\text { fertilizer }\end{array}$ & Meet crop need & {$[157]$} \\
\hline Stem end & Significant & Water stress & Meet crop ETc & Eldredge et al. [64] \\
\hline
\end{tabular}

In summary, the impact of irrigation water management on the potato chemical content might be genotype-dependent, however, more collaborative research involving potato breeders, geneticists, crop physiologists, and agronomists should be conducted 
under severe and medium drought stress and under different climates conditions to determine the factors affecting potato tubers chemical contents and the influencing factors.

\subsection{Impact of Irrigation Regime on the Potato Fries and Chips}

Sugar end, also called dark ends, jelly ends, translucent ends and glassy ends [145-149], are the results of physiological disorder in potato under stress conditions with an increase in sugar content in the basal end of the tuber and low starch content. At fry, the processed product presents one dark end and is not appreciated by the consumers. Sugar end can be detrimental for potato growers. Thompson et al. [150] reported that stressed plants accumulate large amounts of sucrose in the basal tissues of the tuber immediately following stress and continue producing adequate amounts of assimilation to support tuber growth Heat stress and water deficit are the factors that induce changes in the activities of certain key carbohydrate metabolizing enzymes shifting the tuber from a starch synthesizing function to one of starch mobilization [59,146,148,150-154]. Under drought conditions, reactive oxygen species can arise and lead to oxidative damage within the cells with an increase in the production of metabolites such as phenyl-propanoids with antioxidant properties, able to scavenge reactive oxygen species [155-158]. Late embryogenesis of abundant proteins and heat proteins is the protection mechanism in drought stressed potato $[72,139,159-165]$ with an accumulation of osmolytes derived from amino acids or carbohydrates [164,166-168]. These amino acids cause a bitter and astringent taste called egumi-taste in cooked or processed potato tubers [169]. Other studies have shown that excessive nitrogen fertilizer rates $[170,171]$ and inadequate phosphorus fertilizer [172] are other factors of the sugar end in potatoes. Eldredge et al. [64] found a significant darkening in the average stem-end fry color light reflectance of water-stressed Russet Burbank tubers at harvest and during the post-harvest period. Water deficits in potatoes throughout the growing season decreased photosynthesis and assimilate remobilization [173] and consequently fry potato presents pronounced sugar end while it was moderated when plants are subjected to a short duration of water stress [65].

\subsection{Best Irrigation Management in Potatoes}

From the aforementioned research results, water management in potato appears not straightforward. Irrigation management in potatoes like other crops should follow principles of plant-water relationships, irrigation scheduling, monitoring soil moisture across potato root zone throughout the growing season, relationship irrigation and potato growth stages, and considering irrigation and common scab and other characteristics of the product for the target market. Best water management practices must take into account environmental sustainability and economic profitability. For accuracy of irrigation matching crop actual evapotranspiration, potato growers need to learn at least one way to measure or estimate crop evapotranspiration, follow trends in soil moisture content and or soil water matric potential, and keep track of soil water storage and crop evapotranspiration [174]. The first option is to meet crop water requirement which depends on crop growth stages, crop environment, and other management practices. The guidelines proposed by Allen et al. [175] are a great tool for estimating crop evapotranspiration using local weather data and the adjusted proposed crop coefficients to potato height [27,176-178]. Potato is considered to be extremely sensitive to water stress during the tuber initiation and tuber bulking stages and any water deficit during these stages will affect crop yield and quality and the net economic return of the production system. Different available soil moisture sensors could be used for real-time soil storage management that helps to avoid water stress on the potato plant anytime the triggering point or the lower soil storage threshold is reached. Potato growers should consider $60 \mathrm{~cm}$ as the maximum potato plant root zone in the irrigation depth estimation and assure uniform water distribution. Under limited water availability, deficit irrigation is a great option for increasing potato water use efficiency however, the threshold should be set according to the soil type, water availability, and economic profit targets. In arid and semiarid conditions with hot air temperatures, it is recommended 
to use an overhead irrigation system to limit mite infestation. Crop producers should refer to extension agents and or crop consultants or university researchers with any doubt about any uncommon phenomenon observed on the plants in their field for advice and problem-solving.

\section{Conclusions}

This review explored the effects of irrigation management on potato yield and quality, production function, diseases, and pests in potatoes. While targeting one objective can lead to other problems, potato growers should be aware of the contrasting results. However, the best irrigation management practices should be adopted to optimize the production system as suggested by Shock et al. [154]. Potato is a shallow-rooted crop and very sensitive to water stress. Basically, irrigation depth should match for evapotranspiration and any over-irrigation may promote the occurrence of diseases while water stress results in tremendous yield reduction and alters the profitability of the production system. To cope with climate change and production sustainability, smart and precision irrigation is recommended. Different decision tools are available to assist potato growers to achieve profitable and sustainable potato production. However, multidisciplinary studies including but not limited to agronomists, crop physiologists, irrigation engineers, potato breeders, entomologists, environmental engineers and pathologists, and economists may be conducted for an integrated approach to improve potato productivity and system sustainability under different climatic conditions.

Author Contributions: Conceptualization, K.D., S.I.; methodology, K.D., S.I., K.K., S.A.; writingoriginal draft preparation, K.D.; writing-review and editing, K.D., S.I., K.K., S.A. All authors have read and agreed to the published version of the manuscript.

Funding: This research received no external funding.

Institutional Review Board Statement: Not applicable.

Informed Consent Statement: Not applicable.

Data Availability Statement: Not applicable.

Conflicts of Interest: The authors declare no conflict of interest.

\section{References}

1. FAOSTAT. 2019. Available online: http://www.fao.org/faostat/en/\#data/QC (accessed on 27 December 2020).

2. United States Department of Agriculture (USDA). Potatoes 2019 Summary; USDA: Washington, DC, USA, 2020.

3. Vreugdenhil, D.; Bradshaw, J.; Gebhardt, C.; Govers, F.; Mackerron, D.K.L.; Taylor, M.A.; Ross, H.A. Potato Biology and Biotechnology: Advances and Perspectives; Elsevier: Oxford, UK, 2011.

4. FAO. Potato and Water Resources; Hidden Treasure: International Year of the Potato. 2008. Available online: http://www. potato2008.org/en/potato/water.html (accessed on 22 December 2020).

5. CIP. Agricultural Research for Development: Potato Facts and Figures. 2013. Available online: http:// cipotato.org/potato/facts (accessed on 22 December 2020).

6. Yamaguchi, J.; Tanaka, A. Quantitative observation on the root system of various crops growing in the field. Soil Sci. Plant Nutr. 1990, 36, 483-493. [CrossRef]

7. Iwama, K.; Hukushima, T.; Yoshimura, T.; Nakaseko, K. Influence of planting density on root growth and yield in potato. Jpn. J. Crop Sci. 1993, 62, 628-635. [CrossRef]

8. Opena, G.B.; Porter, G.A. Soil management and supplemental irrigation effects on potato: I. Root growth. Agron. J. 1999, 91, 426-431. [CrossRef]

9. Onder, S.; Caliskan, M.E.; Onder, D.; Caliskan, S. Different irrigation methods and water stress effects on potato yield and yield components. Agric. Water Manag. 2005, 73, 73-86. [CrossRef]

10. Stalham, M.A.; Allen, E.J.; Rosenfeld, A.B.; Herry, F.X. Effects of soil compaction in potato (Solanum tuberosum) crops. J. Agric. Sci. 2007, 145, 295-312. [CrossRef]

11. Ahmadi, S.H.; Plauborg, F.; Andersen, M.N.; Sepaskhah, A.R.; Jensen, C.R.; Hansen, S. Effects of irrigation strategies and soils on field grown potatoes: Root distribution. Agric. Water Manag. 2011, 98, 1280-1290. [CrossRef]

12. Quiroz, R.; Chujoy, E.; Mares, V. Potato. In Crop Yield Response to Water; FAO Irrig Drain Paper; Steduto, P., Hsiao, T., Fereres, E., Raes, D., Eds.; FAO: Rome, Italy, 2012; Volume 66, pp. 184-189. 
13. Zarzyńska, K.; Boguszewska-Mańkowska, D.; Nosalewicz, A. Differences in size and architecture of the potato cultivars root system and their tolerance to drought stress. Plant Soil Environ. 2017, 63, 159-164.

14. Deblonde, P.M.K.; Ledent, J.F. Effects of moderate drought conditions on green leaf number, stem height, leaf length and tuber yield of potato cultivars. Eur. J. Agron. 2001, 14, 31-41. [CrossRef]

15. Schittenhelm, S.; Sourell, H.; Lopmeier, F.J. Drought resistance of potato cultivars with contrasting canopy architecture. Eur. J. Agron. 2006, 24, 193-202. [CrossRef]

16. Soltys-Kalina, D.; Plich, J.; Strzelczyk, D.; Sliwka, J.; Marczewski, W. The effect of drought stress on the leaf relative water content and tuber yield of a half-sib family of 'Katahdin'-derived potato cultivars. Breed. Sci. 2016, 66, 328-331. [CrossRef]

17. Romero, A.P.; Alarcon, A.; Galeano, C. Physiological assessment of water stress in potato using spectral information. Front. Plant Sci. 2017, 8, 1608. [CrossRef] [PubMed]

18. Doorenbos, J.; Kassam, A.H. Yield response to water. In FAO Irrigation and Drainage Paper; No. 33; FAO: Rome, Italy, $1979 ;$ p. 193.

19. Haverkort, A.J. Water Management in Potato Production (Technical Information Bulletin 15); International Potato Center (CIP): Lima, Peru, 1982.

20. Dimitrov, S. Evapotranspiration of late potatoes. Field Crop Abst. 1989, r36, 252.

21. Wolfe, R.R.; Goodenough, R.D.; Burke, J.F.; Wolfe, M.H. Response of protein and urea kinetics in burn patients to different levels of protein intake. Ann. Surg. 1983, 197, 163-171. [CrossRef] [PubMed]

22. Hane, D.C.; Pumphrey, F.V. Yield-evapotranspiration relationships and seasonal crop coefficients for frequently irrigated potatoes. Am. Potato J. 1984, 61, 661-668. [CrossRef]

23. Sood, M.C.; Singh, N. Water management. In the Potato: Production and Utilization in Sub-Tropics; Khurana, S.M.P., Minhas, J.S., Pandey, S.K., Eds.; Mehta Publishers: New Dehli, India, 2003; pp. 111-112.

24. Ortega, J.F.; de Juan, J.A.; Tarjuelo, J.M.; López, E. MOPECO: An economic optimization model for irrigation water management. Irrig. Sci. 2004, 23, 61-75. [CrossRef]

25. Karam, F.; Amacha, N.; Fahed, S.; El Asmar, T.; Domínguez, A. Response of potato to full and deficit irrigation under semiarid climate: Agronomic and economic implications. Agric. Water Manag. 2014, 142, 144-151. [CrossRef]

26. El-Abedin, Z.T.K.; Mattar, M.A.; Alazba, A.A.; Al-Ghobari, H.M. Comparative effects of two water-saving irrigation techniques on soil water status, yield, and water use efficiency in potato. Sci. Hortic. 2017, 225, 525-532. [CrossRef]

27. Paredes, P.; D’Agostino, D.; Assif, M.; Todorovic, M.; Pereira, L.S. Assessing potato transpiration, yield and water productivity under various water regimes and planting dates using the FAO dual Kc approach. Agric. Water Manag. 2018, 195, 11-24. [CrossRef]

28. Chen, Y.; Chai, S.; Tian, H.; Chai, Y.; Li, Y.; Chang, L.; Cheng, H. Straw strips mulch on furrows improves water use efficiency and yield of potato in a rainfed semiarid area. Agric. Water Manag. 2019, 211, 142-151. [CrossRef]

29. Katerji, N.; Mastrorilli, M.; Lahmar, F. FAO-56 methodology for the stress coefficient evaluation under saline environment conditions: Validation on potato and broad bean crops. Agric. Water Manag. 2011, 98, 588-596. [CrossRef]

30. Parent, A.C.; Anctil, F. Quantifying evapotranspiration of a rainfed potato crop in Southeastern Canada using eddy covariance techniques. Agric. Water Manag. 2012, 113, 45-56. [CrossRef]

31. Yactayo, W.; Ramírez, D.A.; Gutiérrez, R.; Mares, V.; Posadas, A.; Quiroz, R. Effect of partial root-zone drying irrigation timing on potato tuber yield and water use efficiency. Agric. Water Manag. 2013, 123, 65-70. [CrossRef]

32. Fandika, I.R.; Kemp, P.D.; Millner, J.P.; Horne, D.; Roskruge, N. Irrigation and nitrogen effects on tuber yield and water use efficiency of heritage and modern potato cultivars. Agric. Water Manag. 2016, 170, 148-157. [CrossRef]

33. Kiziloglu, F.M.; Sahin, U.; Tunc, T.; Diler, S. The effect of deficit irrigation on potato evapotranspiration and tuber yield under cool season and semiarid climatic conditions. J. Agron. 2006, 5, 284-288.

34. Ati, A.S.; Iyada, A.D.; Najim, S.M. Water use efficiency of potato (Solanum tuberosum L.) under different irrigation methods and potassium fertilizer rates. Ann. Agric. Sci. 2012, 57, 99-103. [CrossRef]

35. Ferreira, T.C.; Carr, M.K.V. Responses of potatoes (Solanum tuberosum L.) to irrigation and nitrogen in a hot dry climate. I. water use. Field Crops Res. 2002, 78, 51-64. [CrossRef]

36. Erdem, T.; Erdem, Y.; Orta, H.; Okursoy, H. Water-yield relationships of potato under different irrigation methods and regimens. Sci. Agric. 2006, 63, 226-231. [CrossRef]

37. Ierna, A.; Mauromicale, G. Potato growth, yield and water productivity response todifferent irrigation and fertilization regimes. Agric. Water Manag. 2018, 201, 21-26. [CrossRef]

38. Shock, C.; Feibert, E.; Saunders, L. 'Umatilla Russet' and 'Russet Legend' potato yield and quality response to irrigation. Hortic. Sci. 2003, 38, 1117-1121. [CrossRef]

39. Aksic, M.; Gudzic, S.; Deletić, N.; Gudzic, N.; Stojkovic, S.; Knezevic, J. Tuber yield and evapotranspiration of potato depending on soil matric potential. Bulg. J. Agric. Sci. 2014, 20, 122-126.

40. Weatherhead, K.; Knox, J. Irrigation potatoes three trickle irrigation for potatoes. Irrig. News 1998, 27, $19-28$.

41. Rolbiecki, R.; Rolbiecki, S.; Figas, A.; Jagosz, B.; Stachowski, P.; Sadan, H.A.; Prus, P.; Pal-Fam, F. Requirements and Effects of Surface Drip Irrigation of Mid-Early Potato Cultivar Courage on a Very Light Soil in Central Poland. Agronomy 2021, 11, 33. [CrossRef]

42. Slatni, A.; Zayani, K.; Zairi, A.; Yacoubi, S.; Salvador, R.; Playán, E. Assessing alternate furrow strategies for potato at the Cherfech irrigation district of Tunisia. Biosyst. Eng. 2011, 108, 154-163. [CrossRef] 
43. Xie, K.; Wang, X.-X.; Zhang, R.; Gong, X.; Zhang, S.; Mares, V.; Gavilán, C.; Posadas, A.; Quiroz, R. Partial root-zone drying irrigation and water utilization efficiency by the potato crop in semi-arid regions in China. Sci. Hortic. 2012, 134, 20-25. [CrossRef]

44. Sarker, K.K.; Hossain, A.; Timsina, J.; Biswas, S.K.; Kundu, B.C.; Barman, A.; Murad, K.F.I.; Akter, F. Yield and quality of potato tuber and its water productivity are influenced by alternate furrow irrigation in a raised bed system. Agric. Water Manag. 2019, 224, 105750. [CrossRef]

45. Trout, T.J.; Kincaid, D.C.; Westermann, D.T. Comparison of Russet Burbank yield and quality under furrow and sprinkler irrigation. Am. Potato J. 1974, 71, 15-28. [CrossRef]

46. Singh, G. A review of the soil-moisture relationship in potatoes. Am. Potato J. 1969, 46, 398-403. [CrossRef]

47. Jensen, C.R.; Battilani, A.; Plauborg, F.; Psarras, G.; Chartzoulakis, K.; Janowiak, F.; Stikic, R.; Jovanovic, Z.; Li, G.; Qi, X.; et al. Deficit irrigation based on drought tolerance and root signalling in potatoes and tomatoes. Agric. Water Manag. 2010, 98, 403-413. [CrossRef]

48. Camargo, D.C.; Montoya, F.; Córcoles, J.I.; Ortega, J.F. Modeling the impacts of irrigation treatments on potato growth and development. Agric. Water Manag. 2015, 150, 119-128. [CrossRef]

49. Karam, F.; Lahoud, R.; Masaad, R.; Stephan, C.; Rouphael, Y.; Colla, G. Yield and tuber quality of potassium treated potato under optimum irrigation conditions. Acta Hortic. 2005, 684, 103-108. [CrossRef]

50. Foti, S.; Mauromicale, G.; Ierna, A. Influence of irrigation levels on growth and yield of potato cv. Spunta. Potato Res. 1995, 38, 307-318. [CrossRef]

51. Karafyllidis, D.I.; Stavropoulos, N.; Georgakis, D. The effect of water stress on the yielding capacity of potato crops and subsequent performance of seed tubers. Potato Res. 1996, 39, 153-163. [CrossRef]

52. Iqbal, M.; Shah, S.M.; Mohammad, W.; Naway, H. Field response of potato subjected at different growth stages. In Crop Yield Response to Deficit Irrigation; Kirda, C., Moutonnet, P., Hera, C., Nielson, D.R., Eds.; Kluwer Academic Publishers: Dordrecht, The Netherlands, 1999; pp. 213-223.

53. Kirda, C.R. Deficit irrigation scheduling based on plant growth stages showing water stress tolerance. In Deficit Irrigation Practices; Water Reports 22; FAO, Ed.; Food and Agriculture Organization of the United Nations: Rome, Italy, 2002; pp. 3-10.

54. Steyn, J.M.; Du Plessis, H.F.; Fourie, P.; Hammes, P.S. Yield response of potato genotypes to different soil water regimes in contrasting seasons of a subtropical climate. Potato Res. 1998, 41, 239-254. [CrossRef]

55. Kashyap, P.S.; Panda, R.K. Effect of irrigation scheduling on potato crop parameters under water stressed conditions. Agric. Water Manag. 2003, 59, 49-66. [CrossRef]

56. Lahlou, O.; Ledent, J.-F. Root mass and depth, stolons and roots formed on stolons in four cultivars of potato under water stress. Eur. J. Agron. 2005, 22, 159-173. [CrossRef]

57. Fleisher, D.H.; Timlin, D.J.; Reddy, V.R. Elevated carbon dioxide and waterstress effects on potato canopy gas exchange, water use, and productivity. Agric. For. Meteorol. 2008, 148, 1109-1122. [CrossRef]

58. Kleinkopf, G.E. Potato. In Crop Water Relations; Teare, J.D., Peat, M.M., Eds.; Wiley and Sons: New York, NY, USA, 1983; pp. 287-305.

59. Shock, C.C.; Zalewski, J.C.; Stieber, T.D.; Burnett, D.S. Impact of early-season water deficits on russet Burbank plant development, tuber yield and quality. Am. Potato J. 1992, 69, 793-803. [CrossRef]

60. Cappaert, M.R.; Powelson, M.L.; Christensen, N.W.; Stevenson, W.R.; Rouse, D.I. Assessment of irrigation as a method of managing potato early dying. Phytopathology 1994, 84, 792-800. [CrossRef]

61. Martin, M.W.; Miller, D.E. Variations in responses of potato germplasm to deficit irrigation as affected by soil texture. Am. Potato J. 1983, 60, 671-683. [CrossRef]

62. Miller, D.E.; Martin, M.W. Effect of declining or interrupted irrigation on yield and quality of three potato cultivars grown on sandy soil. Am. Potato J. 1987, 64, 109-117. [CrossRef]

63. Miller, D.E.; Martin, M.W. The effect of irrigation regime and subsoiling on yield and quality of three potato cultivars. Am. Potato J. 1986, 64, 17-25. [CrossRef]

64. Eldredge, E.P.; Holmes, Z.A.; Mosley, A.R.; Shock, C.C.; Stieber, T.D. Effects of transitory water stress on potato tuber stem-end reducing sugar and fry color. Am. Potato J. 1996, 73, 517-530. [CrossRef]

65. Shock, C.C.; Feibert, E.B.G.; Saunders, L.D. Potato yield and quality response to deficit irrigation. HortScience 1998, 33, 655-659. [CrossRef]

66. Fabeiro, C.; de Santa Olalla, F.M.; de Juan, J.A. Yield and size of deficit irrigated potatoes. Agric. Water Manag. 2001, 48, 255-266. [CrossRef]

67. Brocic, Z.; Jovanovic, Z.; Stikic, R.; Radovic, B.V.; Mojevic, M. Partial root drying: New approach for potato irrigation. Cereal Res. Commun. 2009, 37, 229-232.

68. Yuan, B.-Z.; Nishiyama, S.; Kang, Y. Effect different irrigation regimes on the growth and yield of drip-irrigated potato. Agric. Water Manag. 2003, 63, 153-167. [CrossRef]

69. Miller, D.E.; Martin, M.W. Responses of three early potato cultivars to subsoiling and irrigation regime on a sandy soil. Am. Potato J. 1990, 67, 769-777. [CrossRef]

70. Byrd, S.A.; Rowland, D.L.; Bennett, J.; Zotarelli, L.; Wright, D.; Alva, A.; Nordgaard, J. Reductions in a commercial potato irrigation schedule during tuberbulking in Florida: Physiological, yield, and quality effects. J. Crop Improv. 2014, 28, 660-679. [CrossRef] 
71. Wang, X.; Guo, T.; Wang, Y.; Xing, Y.; Wang, Y.; He, X. Exploring the optimization of water and fertilizer management practices for potato production in the sandy loam soils of Northwest China based on PCA. Agric. Water Manag. 2020, 237, 106180. [CrossRef]

72. Elhani, S.; Haddadi, M.; Csákvári, E.; Zantar, S.; Hamim, A.; Villányi, V.; Douaik, A.; Bánfalvi, Z. Effects of partial root-zone drying and deficit irrigation on yield, irrigation water-use efficiency and some potato (Solanum tuberosum L.) quality traits under glasshouse conditions. Agric. Water Manag. 2019, 224, 105745. [CrossRef]

73. Islam, T.; Sarker, H.; Alam, J.; Rashid, H.U. Water use and yield relationships of irrigated potato. Agric. Water Manag. 1990, 18, 173-179. [CrossRef]

74. Unlu, M.; Kanber, R.; Senyigit, U.; Onaran, H.; Diker, K. Trickle and sprinkler irrigation of potato (Solanum tuberosum L.) in Middle Anatolian Region in Turkey. Agric. Water Manag. 2006, 79, 43-71. [CrossRef]

75. Ayas, S.; Korukçu, A. Water-yield relationships in deficit irrigated potato. J. Agric. Fac. Uludag Univ. 2010, $24,23-36$.

76. Cantore, V.; Yamaç, S.S.; Albrizio, R.; Stellacci, A.M.; Todorovic, M. Yield and water use efficiency of early potato grown under different irrigation regimes. Int. J. Plant Prod. 2014, 8, 409-428.

77. Ross, C.W. The effect of subsoiling and irrigation on potato production. Soil Tillage Res. 2006, 7, 315-325. [CrossRef]

78. Badr, M.A.; El-Tohamy, W.A.; Zaghloul, A.M. Yield and water use efficiency of potato grown under different irrigation and nitrogen levels in an arid region. Agric. Water Manag. 2012, 110, 9-15. [CrossRef]

79. English, M.J. Deficit irrigation. I: Analytical framework. J. Am. Soc. Civil Eng. 1990, 116, 399-412. [CrossRef]

80. English, M.J.; Musick, J.T.; Murty, V.V.N. Deficit irrigation. In Management of Farm Irrigation Systems; Hoffman, G.J., Soloman, K.H., Eds.; American Society of Agricultural Engineers: St. Joseph, MI, USA, 1990; pp. 631-663.

81. DaCosta, M.; Huang, B. Deficit irrigation effects on water use characteristics of Bent grass species. Crop Sci. 2006, 46, 1779-1786. [CrossRef]

82. Saeed, H.; Grove, I.G.; Kettlewell, P.S.; Hall, N.W. Potential of partial root zone drying as an alternative irrigation technique for potatoes (Solanum tuberosum). Ann. Appl. Biol. 2008, 152, 71-80. [CrossRef]

83. Geerts, S.; Raes, D. Deficit irrigation as an on-farm strategy to maximize crop water productivity in dry areas. Agric. Water Manag. 2009, 96, 1275-1284. [CrossRef]

84. Djaman, K.; Irmak, S.; Rathje, W.R.; Martin, D.L.; Eisenhauer, D.E. Maize evapotranspiration, yield production function, biomass, grain yield, harvest index, and yield response factors under full and limited irrigation. Trans. ASABE 2013, 56, 273-293. [CrossRef]

85. Ahmadi, S.H.; Andersen, M.N.; Plauborg, F.; Poulsen, R.T.; Jensen, C.R.; Sepaskhah, A.R.; Hansen, S. Effects of irrigation strategies and soils on field grown potatoes: Yield and water productivity. Agric. Water Manag. 2010, 97, 1923-1930. [CrossRef]

86. Ahmadi, S.H.; Andersen, M.N.; Plauborg, F.; Poulsen, R.T.; Jensen, C.R.; Sepaskhah, A.R.; Hansen, S. Effects of irrigation strategies and soils on field grown potatoes: Gas exchange and xylem [ABA]. Agric. Water Manag. 2010, 97, 1486-1494. [CrossRef]

87. Trebejo, I.; Midmore, D.J. Effect of water stress on potato growth, yield and water use in a hot and a cool tropical climate. J. Agric. Sci. 1990, 114, 321-334. [CrossRef]

88. Ahmadi, S.H.; Agharezaee, M.; Kamgar-Haghighib, A.A.; Sepaskhah, A.R. Effects of dynamic and static deficit and partial root zone drying irrigation strategies on yield, tuber sizes distribution, and water productivity of two field grown potato cultivars. Agric. Water Manag. 2014, 134, 126-136. [CrossRef]

89. Carli, C.; Yuldashev, F.; Khalikov, D.; Condori, B.; Mares, V.; Monneveux, P. Effect of different irrigation regimes on yield, water use efficiency and quality of potato (Solanum tuberosum L.) in the lowlands of Tashkent, Uzbekistan: A field and modeling perspective. Field Crops Res. 2014, 163, 90-99. [CrossRef]

90. Liu, F.; Shahnazari, A.; Andersen, M.N.; Jacobsen, S.E.; Jensen, C.R. Physiological responses of potato (Solanum tuberosum L.) to partial root-zone drying: ABA signaling, leaf gas exchange, and water use efficiency. J. Exp. Bot. 2016, 57, 3727-3735. [CrossRef]

91. Kriedmann, P.E.; Goodwin, I. Regulated Deficit Irrigation and Partial Root-Zone Drying; Irrigation Insights No. 4; Land and Water Australia: Canberra, Australia, 2003; p. 102.

92. Saeed, H.; Grove, I.G.; Kettlewell, P.S.; Hall, N.W. Potato root and shoot growth under different water management strategies. Asp. Appl. Biol. 2005, 73, 85-91.

93. Sepaskhah, A.R.; Parand, A.R. Effects of alternate furrow irrigation with supplemental every-furrow irrigation at different growth stages on the yield of maize (Zea mays L.). Plant Prod. Sci. 2006, 9, 415-421. [CrossRef]

94. Shahnazari, A.; Ahmadi, S.H.; Laerke, P.E.; Liu, F.; Plauborg, F.; Jacobsen, S.E.; Jensen, C.R.; Andersen, M.N. Nitrogen dynamics in the soil-plant system under deficit and partial root-zone drying irrigation strategies in potatoes. Eur. J. Agron. 2008, $28,65-73$. [CrossRef]

95. Shahnazari, A.; Liu, F.; Andersen, M.N.; Jacobsen, S.E.; Jensen, C.R. Effects of partial root-zone drying on yield, tuber size and water use efficiency in potato under field conditions. Field Crops Res. 2007, 100, 117-124. [CrossRef]

96. Jovanovic, Z.; Stikic, R.; Vucelic-Radovic, B.; Paukovic, M.; Brocic, Z.; Matovic, G.; Rovcanin, S.; Mojevic, M. Partial root-zone drying increases WUE, $\mathrm{N}$ and antioxidant content in field potatoes. Eur. J. Agron. 2010, 33, 124-131. [CrossRef]

97. Liu, F.; Shahnazari, A.; Andersen, M.N.; Jacobsen, S.E.; Jensen, C.R. Effects of deficit irrigation (DI) and partial root drying (PRD) on gas exchange, biomass partitioning, and water use efficiency in potato. Sci. Hortic. 2006, 109, 113-117. [CrossRef]

98. Adams, S.S.; Stevenson, W.R. Water management, disease development, and potato production. Am. Potato J. 1990, 67, 3-11. [CrossRef]

99. Nuñez, J.; Haviland, D.R.; Aegerter, B.J.; Baldwin, R.A.; Westerdahl, B.B.; Trumble, J.T.; Wilson, R.G. Revised continuously. In UC IPM Pest Management Guidelines: Potato; UC ANR Publication 3463: Oakland, CA, USA, 2019. 
100. Menzies, J.D. Plant diseases related to irrigation. In Irrigation of Agricultural Lands; No. 11 in the series Agronomy; Hagan, R.M., Ed.; American Society of Agronomy: Madison, WI, USA, 1967; pp. 1058-1964.

101. Van Loon, C.D. The effect of water stress on potato growth, development, and yield. Am. Potato J. 1981, 58, 51-70. [CrossRef]

102. Rupp, J.; Jacobsen, B. Bacterial and Fungal Diseases of Potato and Their Management; Extension Bulletin; Montana State University: Bozeman, MT, USA, 2017. Available online: http:/ / www.montanaspud.org/documents/extension-information/potatoes12-27-3 .pdf (accessed on 22 December 2020).

103. Olanya, O.M.; Starr, G.C.; Honeycutt, C.W.; Griffin, T.S.; Lambert, D.H. Microclimate and potential for late blight development in irrigated potato. Crop Prot. 2007, 26, 1412-1421. [CrossRef]

104. Larkin, R.P.; Honeycutt, C.W.; Griffin, T.S.; Olanya, O.M.; Halloran, J.M.; He, Z. Effects of different potato cropping system approaches and water management on soilborne diseases and soil microbial communities. Phytopathology 2011, 101, 58-67. [CrossRef] [PubMed]

105. Lapwood, D.H.; Wellings, L.W.; Hawkins, J.H. Irrigation as a practical means to control potato common scab (Streptomyces scabies): Final experiment and conclusions. Plant Pathol. 1973, 22, 35-41. [CrossRef]

106. Davis, J.R.; McMaster, G.M.; Callihan, R.H.; Nissley, F.H.; Pavek, J.J. Influence of soil moisture and fungicide treatments on common scab and mineral content of potatoes. Phytopathology 1976, 66, 228-233. [CrossRef]

107. Davis, J.R.; Everson, D.O. Relation of Verticillium ahlia in soil and potato tissue, irrigation method and N-fertility to Verticillium wilt of potato. Phytopathology 1986, 76, 730-736. [CrossRef]

108. Munyaneza, J.E.; Goolsby, J.A.; Crosslin, J.M.; Upton, J.E. Further evidence that zebra chip potato disease in the lower Rio Grande Valley of Texas is associated with Bactericera cockerelli. Subtrop. Plant. Sci. 2007, 59, 30-37.

109. Sengoda, V.G.; Munyaneza, J.E.; Crosslin, J.M.; Buchman, J.L.; Pappu, H.R. Phenotypic and etiological differences between psyllid yellows and zebra chip diseases of potato. Am. J. Potato Res. 2010, 87, 41-49. [CrossRef]

110. Crosslin, J.M.; Hamm, P.B.; Eggers, J.E.; Rondon, S.I.; Sengoda, V.G.; Munyaneza, J.E. First report of zebrachip disease and "Candidatus Liberibacter solanacearum" on potatoes in Oregon and Washington. Plant. Dis. 2012, 96, 452. [CrossRef] [PubMed]

111. Vereijssen, J.; Grant, R.G.; Phyllis, G.W. Bactericera cockerelli (Hemiptera: Triozidae) and Candidatus Liberibacter solanacearum in Potatoes in New Zealand: Biology, Transmission, and Implications for Management. J. Integr. Pest. Manag. 2018, 9, 1-21. [CrossRef]

112. Djaman, K.; Higgins, C.; Begay, S.; Koudahe, K.; Allen, S.; Lombard, K.; O’Neill, M. Seasonal occurrence of potato psyllid (Bactericera cockerelli) and risk of zebra chip pathogen (Candidatus liberibacter solanacearum) in Northwestern New Mexico. Insects 2020, 11, 3. [CrossRef]

113. Yi Xu, Y.; Gray, S.M. Aphids and their transmitted potato viruses: A continuous challenges in potato crops. J. Integr. Agric. 2020, 19, 367-375.

114. Haviland, D.R.; Trumble, J.T. UC IPM Pest Management Guidelines: Potato; UC ANR Publication 3463: Oakland, CA, USA, 2020.

115. Van Hoof, H.A. Aphid vectors of potato virus Y. Neth. J. Plant Pathol. 1980, 86, 159-162. [CrossRef]

116. Kim, J.; Cha, D.J.; Kwon., M.; Maharjan, R. Potato virus Y (PVY) detection in a single aphid by one-step RT-PCR with boiling technique. Entomol. Res. 2016, 46, 278-285. [CrossRef]

117. Schreiber, A.; Jensen, A.; Rondon, S.; Wenninger, E.; Reitz, S.; Waters, T. Integrated Pest Management Guidelines for Insects and Mites in Idaho, Oregon and Washington Potatoes; Northwest Insect Management Guidelines; Northwest Potato Research Consortium location: Lakeview, OR, USA, 2019; p. 75.

118. Rondon, S.I. Pest Management Strategies for Potato Insect Pests in the Pacific Northwest of the United States, Insecticides-Pest Engineering; Perveen, F., Ed.; InTech: London, UK, 2012; ISBN 978-953-307-895-3.

119. Storch, R.H.; Frank, J.A.; Manzer, F.E. Fungi associated with Collembola and mites isolated from scabby potatoes. Am. Potato J. 1978, 55, 197-201. [CrossRef]

120. Meisner, J.; Ascher, K.R.S.; Lavie, D. Factors influencing the attraction to the potato tuber moth, Gnorimoschema operculella Zeller. J. Appl. Entomol. 1974, 77, 179-189.

121. Foot, M.A. Bionomics of the potato tuber moth, Phthorimaea operculella (Lepidoptera: Gelechiidae) at Pukekohe. N. Zeal. J. Zool. 1979, 6, 623-636. [CrossRef]

122. Rondon, M.A.; Lehmann, J.; Ramirez, J.; Hurtado, M. Biological nitrogen fixation by common beans (Phaseolus vulgaris L.) increases with bio-char additions. Biol. Fertil Soils 2007, 43, 699-708. [CrossRef]

123. Clough, G.H.; Debano, S.J.; Hamm, P.B. 'Reducing Potato Tuber Moth Damage with Cultural Practices and Pesticide Treatments'. In Integrated Pest Management for the Potato Tuber Moth, Phthorimaea operculella Zeller-A Potato Pest of Global Importance; Tropical Agriculture 20, Advances in Crop Research 10; Kroschel, J., Lacey, L., Eds.; Margraf Publishers: Weikersheim, Germany, 2008 ; pp. 101-109.

124. Jensen, T.H.; Boulay, J.; Olesen, J.R.; Colin, J.; Weyler, M.; Domenico Libri, D. Modulation of Transcription Affects mRNP Quality. Mol. Cell. 2004, 16, 235-244. [CrossRef] [PubMed]

125. Hang, A.N.; Miller, D.E. Yield and physiological responses of potatoes to deficit, high frequency sprinkler irrigation. Agron. J. 1986, 78, 436-440. [CrossRef]

126. Waddell, J.T.; Gupta, S.C.; Moncrief, J.F.; Rosen, C.J.; Steele, D.D. Irrigation and nitrogen management effects on potato yield, tuber quality, and nitrogen uptake. Agron. J. 1999, 91, 991-997. [CrossRef] 
127. Porter, G.A.; Opena, G.B.; Bradbury, W.B.; McBurnie, J.C.; Sisson, J.A. Soil management and supplemental irrigation effects on potato. I. Soil properties, tuber yield, and quality. Agron. J. 1999, 91, 416-425. [CrossRef]

128. Drewitt, E.G. The Effect of Irrigation on the Yield and Quality of Potatoes; Technical Report; Winchmore Irrig.: Borehamwood, UK, 1970; p. 29.

129. Harris, P. The Potato Crop, 2nd ed.; Chapman \& Hall: London, UK, 1992; ISBN 0412296403.

130. Peterson, L.E.; Weigle, J.L. Varietal Response of Potatoes to Air Conditioning Irrigation. Am. Potato J. 1970, 47, 94-98. [CrossRef]

131. Silva, G.H.; Chase, R.W.; Hammerschmidt, R.; Vitosh, M.L.; Kitchen, R.B. Irrigation, nitrogen and gypsum effects on specific gravity and internal defects of Atlantic potatoes. Am. Potato J. 1991, 68, 751-765. [CrossRef]

132. Johnson, D.A.; Martin, M.; Cummings, T.F. Effect of chemical defoliation, irrigation water, and dis-tance from the pivot on late blight tuber rot in center-pivot irrigated potatoes in the Columbia Basin. Plant Dis. 2003, 87, 977-982. [CrossRef]

133. Kempenaar, C.; Struik, P.C. The canon of potato science: Haulm killing. Potato Res. 2007, 50, 341-345. [CrossRef]

134. Smith, O. Effect of cultural and environmental conditions on pota- toes for processing. In Potato Processing, 4th ed.; Potato after-cooking darkening; Talburt, W.F., Smith, O., Eds.; Van Nostrand Reihold Company, Inc.: New York, NY, USA, 1987; pp. 108-110. Available online: https://www.researchgate.net/publication/225720033_Potato_after-cooking_darkening (accessed on 5 December 2020).

135. Davies, H.V.; Oparka, K.J. Hexose metabolism in developing tubers of potato (Solanum tuberosum L. ) cv Maris Piper. J. Plant Physiol. 1985, 119, 311-316.

136. Battilani, A.; Jensen, C.R.; Liu, F.; Plauborg, F.; Andersen, M.N.; Solimando, D. Partial root-zone drying (PRD) feasibility on potato in a sub-humid climate. Acta Hortic. 2014, 1038, 487-494. [CrossRef]

137. Wegener, C.B.; Jürgens, H.; Jansen, G. Drought stress affects nutritional and bioactive compounds in potatoes (Solanum tuberosum L.) relevant to human health. Funct. Food Health Dis. 2017, 7, 17-35. [CrossRef]

138. André, C.M.; Schafleitner, R.; Legay, S.; Lefèvre, I.; Aliaga, C.A.A.; Nomberto, G.; Hoffmann, L.; Hausman, J.F.; Larondelle, Y.; Evers, D. Gene expression changes related to the production of phenolic compounds in potato tubers grown under drought stress. Phytochemistry 2009, 70, 1107-1116. [CrossRef]

139. Muttucumaru, N.; Powers, S.J.; Elmore, J.S.; Mottram, D.S.; Halford, N.G. Effects of water availability on free amino acids, sugars, and acrylamide-forming potential in potato. J. Agric. Food Chem. 2015, 63, 2566-2575. [CrossRef]

140. Knorr, D. Protein Quality of the Potato and Potato Protein Concentrates. Lebensm.-Wiss. Technol. 1978, 11, $109-115$.

141. He, M.; Dijkstra, F.A. Drought effect on plant nitrogen and phosphorus: A meta-analysis. New Phytol. 2014, $204,924-931$. [CrossRef]

142. Sun, Y.; Cui, X.; Liu, F. Effect of irrigation regimes and phosphorus rates on water and phosphorus use efficiencies in potato. Sci. Hortic. 2015, 190, 64-69. [CrossRef]

143. Hu, G.; Chen, J.; Gao, J. Preparation and characteristics of oxidized potato starch films. Carbohydr. Polym. 2009, 76, 291-298. [CrossRef]

144. Hamouz, K.; Lachman, J.; Hejtmánková, K.; Pazderů, K.; Čížek, M.; Dvořák, P. Effect of natural and growing conditions on the content of phenolics in potatoes with different flesh colour. Plant Soil Environ. 2010, 56, 368-374. [CrossRef]

145. Everson, D.O.; Austin, J.; Romanko, R.R.; Painter, C.; Hammons, L.; Walz, A.; Muneta, P.; Nielsen, N.; Gross, D.; Jaeger, J.; et al. Translucent ends in Potatoes in Southwestern Idaho; Idaho. Agricultural Research Progress Report No. 170; University of Idaho Research and Extension Center: Aberdeen, ID, USA, 1973.

146. Hiller, L.K.; Thornton, R.E. Management of physiological disorders. In Potato Health Management; Rowe, R.C., Ed.; APS: St. Paul, MN, USA, 1993; pp. 87-94.

147. Kleinkopf, G.E. Translucent end of potatoes. Proc. Univ. Idaho Potato Sch. 1976, 8, 51-61.

148. Kleinkopf, G.E. Translucent end of potatoes. University of Idaho, Cooperative Extension Service, Agricultural Experiment Station, Current Information Series No.488; National Agriculture Library: Beltsville, MA, USA, 1979; 4p.

149. Nielsen, L.W.; Sparks, W.C. Bottleneck Tubers and Jelly-end Rot in the Russet Burbank Potato; Research Bulletin; University of Idaho Agricultural Experiment Station: Parma, Italy, 1953.

150. Thompson, A.L.; Love, S.L.; Sowokinos, J.R.; Thornton, M.K.; Shock, C.C. Review of the sugar end disorder in potato (Solanum tuberosum, L.). Am. J. Potato Res. 2008, 85, 375-386. [CrossRef]

151. Iritani, W.M. Growth and preharvest stress and processing quality of potatoes. Am. Potato J. 1981, 58, 71-80. [CrossRef]

152. Iritani, W.M.; Weller, L.D. Sugar Development in Potatoes; Cooperative Extension; Washington State University: Pullman, WA, USA, 1980.

153. Kincaid, D.C.; Westermann, D.T.; Trout, T.J. Irrigation and soil temperature effects on Russet Burbank quality. Am. Potato J. 1993, 70, 711-723. [CrossRef]

154. Shock, C.C.; Holmes, Z.A.; Stieber, T.D.; Eldredge, E.P.; Zhang, P. The effect of timed water stress on quality, total solids and reducing sugar content of potatoes. Am. Potato J. 1993, 70, 227-241. [CrossRef]

155. Dixon, R.A.; Paiva, N.L. Stress-induced phenylpropanoid metabolism. Plant Cell 1995, 7, 1085-1097. [CrossRef]

156. Cruz de Carvalho, M.H. Drought stress and reactive oxygen species: Production, scavenging and signaling. Plant Signal Behav. 2008, 3, 156-165. [CrossRef]

157. Wegener, C.B.; Jansen, G.; Jürgens, H.U. Bioactive compounds in potatoes: Accumulation under drought stress conditions. Funct. Food Health Dis. 2015, 5, 108-116. [CrossRef] 
158. Drapal, M.; Farfan-Vignolo, E.R.; Gutierrez, O.R.; Bonierbale, M.; Mihovilovich, E.; Fraser, P.D. Identification of metabolites associated with water stress responses in Solanum tuberosum L. clones. Phytochemistry 2017, 135, 24-33. [CrossRef]

159. Nadler, A.; Heuer, B. Effect of saline irrigation and water deficit on tuber quality. Potato Res. 1995, 38, 119-123. [CrossRef]

160. Zhu, Z.; Wei, G.; Li, J.; Qian, Q.; Yuet, J. Silicon alleviates salt stress and increases antioxidant enzymes activity in leaves of salt-stressed cucumber (Cucumis sativus L.). Plant Sci. 2004, 167, 527-533. [CrossRef]

161. Gong, H.; Zhu, X.; Chen, K.; Wang, S.; Zhang, C. Silicon alleviates oxidative damage of wheat plants in pots under drought. Plant Sci. 2005, 169, 313-321. [CrossRef]

162. Watkinson, J.I.; Hendricks, L.; Sioson, A.A.; Heath, L.S.; Bohnert, H.J.; Grene, R. Tuber development phenotypes in adapted and acclimated, drought-stressed Solanum tuberosum ssp. andigena have distinct expression profiles of genes associated with carbon metabolism. Plant Physiol. Biochem. 2008, 46, 34-45. [CrossRef] [PubMed]

163. Crusciol, C.A.C.; Pulz, A.L.; Lemos, L.B.; Soratto, R.P.; Lima, G.P.P. Effects of Silicon and Drought Stress on Tuber Yield and Leaf Biochemical Characteristics in Potato. Crop Sci. 2009, 49, 949-954. [CrossRef]

164. Sprenger, H.; Kurowsky, C.; Horn, R.; Erban, A.; Seddig, S.; Rudack, K.; Fischer, A.; Walther, D.; Zuther, A.; Köhl, K.; et al. The drought response of potato reference cultivars with contrasting tolerance. Plant Cell Environ. 2016, 39, 2370-2389. [CrossRef]

165. Rykaczewska, K. Impact of heat and drought stresses on size and quality of the potato yield. Plant Soil Environ. 2017, 63, 40-46.

166. Schafleitner, R.; Gutierrez, R.O.; Gaudin, A.; Alvarado Aliaga, C.A.; Nomberto Martinez, G.; Tincopa Marca, L.R.; Avila Bolivar, L.; Mendiburu Delgado, F.; Simon, R.; Bonierbale, M. Capturing candidate drought tolerance traits in two native Andean potato clones by transcription profiling of field grown plants under water stress. Plant Physiol. Biochem. 2007, 45, 673-690. [CrossRef]

167. Vasquez-Robinet, C.; Mane, S.P.; Ulanov, A.V.; Watkinson, J.; Stromberg, V.K.; De Koeyer, D.; Schafleitner, R.; Willmot, D.B.; Bonierbale, M.; Bohnert, H.J.; et al. Physiological and molecular adaptations to drought in Andean potato genotypes. J. Exp. Bot. 2008, 59, 2109-2123. [CrossRef]

168. Evers, D.; Lefevre, I.; Legay, S.; Lamoureux, D.; Hausman, J.F.; Rosales, R.O.; Marca, L.R.; Hoffmann, L.; Bonierbale, M.; Schafleitner, R. Identification of drought-responsive compounds in potato through a combined transcriptomic and targeted metabolite approach. J. Expt. Bot. 2010, 61, 2327-2343. [CrossRef]

169. Sato, H.; Koizumi, R.; Itoyama, R.; Ichisawa, M.; Negishi, J.; Sakuma, R.; Furusho, T.; Sagane, Y.; Takano, K. Free Amino Acids in Potato (Solanum tuberosum) May Cause Egumi-Taste in Food Products. Potato Res. 2019, 62, 305-314. [CrossRef]

170. Feibert, E.B.G.; Shock, C.C.; Saunders, L.D. Nitrogen fertilizer requirements of potato using carefully scheduled sprinkler irrigation. HortScience 1998, 33, 262-265.

171. Thornton, R.E.; Iritani, W.M. Sugar end potatoes. Proc. Univ. Ida. Winter Comm. Sch. 1986, 18, $202-210$.

172. Lewis, W.M. Nitrogen and phosphorus runoff losses from a nutrient-poor tropical moist forest. Ecology 1986, 67, 1275-1282. [CrossRef]

173. Shimshi, D.; Shalhevet, J.; Meir, T. Irrigation regime effects on some physiological responses of potato. Agron. J. 1983, 75, $262-267$. [CrossRef]

174. Shock, C.C.; Pereira, A.B.; Eldredge, E.P. Irrigation best management practices for potato. Am. J. Potato Res. 2007, 84, 29-37. [CrossRef]

175. Alle Allen, R.; Pereira, L.; Raes, D.; Smith, M. Crop Evapotranspiration. Guideline for Computing Crop Requirements; FAO-Irrigation and Drainage Paper 56; FAO: Rome, Italy, 1998.

176. Allen, R.G.; Pereira, L.S. Estimating crop coefficients from fraction of groundcover and height. Irrig. Sci. 2009, 28, 17-34. [CrossRef]

177. Rosa, R.D.; Paredes, P.; Rodrigues, G.C.; Alves, I.; Fernando, R.M.; Pereira, L.S.; Allen, R.G. Implementing the dual crop coefficient approach in interactive software. 1. Background and computational strategy. Agric. Water Manag. 2012, 103, 8-24. [CrossRef]

178. Pereira, L.S.; Paredes, P.; López-Urrea, R.; Hunsaker, D.J.; Mota, M.; Shad, Z.M. Standard single and basal crop coefficients for vegetable crops, an update of FAO56 crop water requirements approach. Agric. Water Manag. 2021, 243, 106196. [CrossRef] 